How to cite : Lebo, K. G., Joyce Ch. Kumaat, J. C., Maliangkay, M. (2020). Sebaran Hutan Mangrove di Wilayah Pesisir Tobelo Menggunakan Sistem Informasi Geografis. Jurnal Episentrum, 1(3), 28-31. doi: 10.36412/jepst.v1i3.2358

\title{
SEBARAN HUTAN MANGROVE DI WILAYAH PESISIR TOBELO MENGGUNAKAN SISTEM INFORMASI GEOGRAFIS
}

\author{
Kristin G. Lebo ${ }^{1}$, Joyce Ch. Kumaat ${ }^{2}$, Denny Maliangkay ${ }^{3}$ \\ ${ }^{1}$ Mahasiswa Program Studi Geografi, Fakultas Ilmu Sosial, Universitas Negeri Manado \\ ${ }^{2,3}$ Dosen Program Studi Geografi, Fakultas Ilmu Sosial, Universitas Negeri Manado \\ e-mail: kristinglorialebo@gmail.com
}

\begin{abstract}
The aim of this research is to make a map of mangrove forest distribution and to know the dynamics of mangrove forest distribution in the coastal area of Tobelo, North Halmahera Regency. The method used is descriptive quantitative and data analysis using Geographic Information Systems (GIS) with ArGis 10.6 software. The research data were processed from the base map and Landsat 7 imagery data for the period 2000-2020. The result of the analysis shows that there is a change in the distribution of the mangrove coastal mangrove Tobelo within 20 years. In the Landsat 7 level 1 image data, from 2000-2015 the mangrove forest experienced a lot of reduction, while in 2020 the mangrove forest on the Tobelo coast experienced an increase compared to previous years.
\end{abstract}

Keywords: Dynamics, Distribution, Mangrove, GIS

\begin{abstract}
Abstrak: Tujuan dari penelitian adalah untuk membuat peta persebaran hutan mangrove dan mengetahui dinamika luasan sebaran hutan mangrove di wilayah pesisir Tobelo Kabupaten Halmahera Utara. Metode yang digunakan adalah deskriptif kuantitatif dan analisis data menggunakan Sistem Informasi Geografis (SIG) dengan software ArGis 10.6. Data penelitian diolah dari peta dasar dan data citra landsat 7 kurun waktu tahun 2000-2020. Hasil analisis menunjukan adanya perubahan hutan mangrove pesisir tobelo dalam kurun waktu 20 tahun. Pada data citra landsat 7 level 1, tahun 2000-2015 hutan mangrove banyak mengalami pengurangan sedangkan pada tahun 2020 hutan mangrove yang berada di pesisir Tobelo mengalami penambahan dibandingkan dengan tahuntahun sebelumnya.
\end{abstract}

Kata Kunci: Dinamika, Persebaran, Mangrove, SIG

\section{PENDAHULUAN}

Hutan mangrove secara umum merupakan komunitas vegetasi pantai tropis, didominasi oleh beberapa jenis pohon yang mampu tumbuh dan berkembang di daerah pasang surut pantai berlumpur. Perbedaannya dengan hutan lain adalah keberadaan flora dan fauna yang spesifik dengan keanekaragaman jenis yang tinggi. Namun, hutan mangrove rentan terhadap kerusakan apabila lingkungan tidak seimbang (Ritohardoyo dam Ardi, 2011). Bahkan, rusaknya mangrove bukan saja diakibatkan oleh proses alami, tetapi juga akibat aktivitas manusia. Keberadaan eksploitasi hutan mangrove untuk pemenuhan kebutuhan manusia cenderung berlebihan dan tidak mengindahkan kaidah-kaidah konservasi (Dara, K. A. 2015).
Pesisir Tobelo adalah salah satu wilayah di Kabupaten Halmahera Utara yang mempunyai hutan mangrove. Seiring berkembangnya pembangunan dan jumlah penduduk yang meningkat, sebagian hutan mangrove pesisir tobelo telah beralih fungsi lahan sebagai pemukiman, pertambakan dan pembangunan lainnya. Bahkan, masyarakat sudah banyak yang menebang dan dijadikan kayu bakar, sehingga mangrove sudah banyak mengalami kerusakan.

Informasi mengenai persebaran dan dinamika hutan mangrove di pesisir Tobelo merupakan isu-isu strategis yang dapat dijadikan sumber informasi ilmiah di dalam konsep pembangunan berkelanjutan yang menitik beratkan pada isu-isu lingkungan (Iwamony, 2012). 